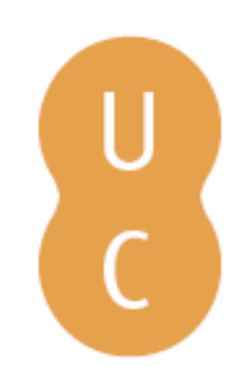

pnmbalina

\title{
Potential impact of climate change on live fuel moisture dynamic at local scale
}
Autor(es):
Pellizzaro, Grazia; Dubrovsky, Martin; Bortolu, Sara; Arca, Bachisio; Ventura, Andrea; Duce, Pierpaolo

Publicado por: Imprensa da Universidade de Coimbra

URL persistente:

URI:http://hdl.handle.net/10316.2/34351

DOI:

DOI:http://dx.doi.org/10.14195/978-989-26-0884-6_134

Accessed : $\quad$ 26-Apr-2023 13:06:30

A navegação consulta e descarregamento dos títulos inseridos nas Bibliotecas Digitais UC Digitalis, UC Pombalina e UC Impactum, pressupõem a aceitação plena e sem reservas dos Termos e Condições de Uso destas Bibliotecas Digitais, disponíveis em https://digitalis.uc.pt/pt-pt/termos.

Conforme exposto nos referidos Termos e Condições de Uso, o descarregamento de títulos de acesso restrito requer uma licença válida de autorização devendo o utilizador aceder ao(s) documento(s) a partir de um endereço de IP da instituição detentora da supramencionada licença.

Ao utilizador é apenas permitido o descarregamento para uso pessoal, pelo que o emprego do(s) título(s) descarregado(s) para outro fim, designadamente comercial, carece de autorização do respetivo autor ou editor da obra.

Na medida em que todas as obras da UC Digitalis se encontram protegidas pelo Código do Direito de Autor e Direitos Conexos e demais legislação aplicável, toda a cópia, parcial ou total, deste documento, nos casos em que é legalmente admitida, deverá conter ou fazer-se acompanhar por este aviso.

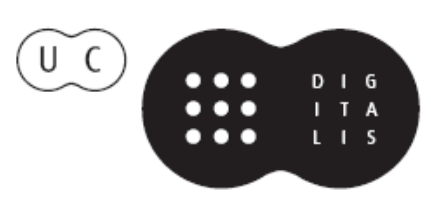




\section{ADVANCES IN}

Forest Fire

\section{RESEARCH}

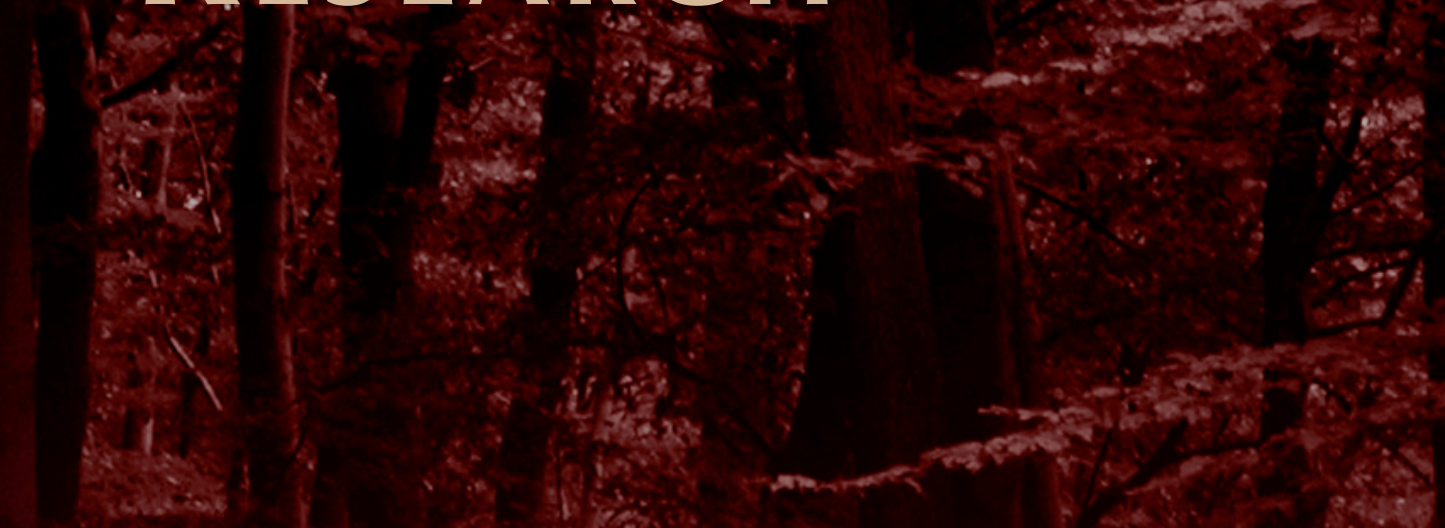

\section{DOMINGOS XAVIER VIEGAS}

\section{EDITOR}




\title{
Potential impact of climate change on live fuel moisture dynamic at local scale
}

\author{
Grazia Pellizzaro $^{\mathrm{a}}$, Martin Dubrovsky ${ }^{\mathrm{b}}$, Sara Bortolu ${ }^{\mathrm{a}}$, Bachisio Arca ${ }^{\mathrm{a}}$, Andrea Ventura ${ }^{\mathrm{a}}$, Pierpaolo \\ Duce $^{\text {a }}$
}

${ }^{a}$ Institute of Biometeorology (CNR-IBIMET), Sassari, Italy, g.pellizzaro@ibimet.cnr.it

${ }^{b}$ Institute of Atmospheric Physics, Praha, Czech Republic

\begin{abstract}
According to projections on future climate, an increase in risk of summer droughts is likely to take place in Southern Europe. More prolonged drought seasons induced by climatic changes are likely to influence general flammability characteristics of fuel, affecting species composition and live and dead fuel ratio. Moreover, variations in precipitation and mean temperature could directly affect live fuel water content, and length of critical periods of high ignition danger for Mediterranean ecosystems. The flammability of vegetation is influenced by several factors that include structural properties, chemical properties and moisture content. Several studies have also highlighted the importance of vegetation moisture content in relation to ignition and rate of spread in Mediterranean shrubs.

The main aim of this work was to propose a method for evaluating possible impacts of future climate change on live moisture dynamic and length of fire danger period at local scale by using weather generator techniques. In particular, in this work i) threshold values for drought indices that indicate the end of fire season due to live fuel status in Mediterranean shrubland were identified, and ii) potential impacts at local scale of future climate changes on the duration of fire danger period were simulated. The study was carried out in Sardinia (Italy). Moisture content of live fuel (LFMC) was determined periodically for 8 years on three shrub species. Seasonal patterns of LFMC were compared with the Drought Code (DC) of the Canadian Forest Fire Weather Index and the Keetch-Byram Drought Index. A threshold value of DC useful to determine the end of the potential fire season due to fuel status was identified. A weather generator linked to climate change scenarios derived from 17 available General Circulation Models (GCMs) was used to produce synthetic weather series, representing future climates, and then the expected changes of the fire season length was determined. Results confirmed that the projected climate scenarios over the Mediterranean area will determine an overall increase of the fire season length.
\end{abstract}

Keywords: Forest fires, Mediterranean shrubs, Fuel status, Fire danger season

\section{Introduction}

Shrubs are an important component of Mediterranean vegetation: live shrubs are often the main component of the available fuel which catches fire and constitute the surface fuels primarily responsible for the ignition and the spread of wildland fires.

Vegetation flammability is influenced by several factors including structural properties, chemical properties and moisture content. However, it is well known that moisture content of plants is an essential factor influencing the fire ignition and spread. Several authors have found relationships between vegetation water content and ignitability in several Mediterranean species (Hernando et al.1994; Dimitrakopoulos and Papaioannou 2001; Pellizzaro et al. 2007). Some authors highlighted the importance of vegetation moisture content in relation to crown fire potential, ignition and rate of spread in shrubs (Van Wagner 1977; Chandler et al. 1983; Agee et al. 2002; Davis et al. 2009). Studies carried out in Mediterranean areas have shown that burned areas tend to increase as live fuel moisture decreases (Davis et al. 1995; Schoenberg et al. 2003; Chuvieco et al. 2004; Dennison et al. 2008). The relationship between fire occurrence and drought is well known; forest fires mainly occur during dry summer periods when air temperature is high, air humidity is low and fuel moisture reduced (Piñol 
et al. 1998). According to projections on future climate, an increase in risk of summer droughts is likely to take place in Southern Europe (Giorgi et al. 2004; Giannakopoulos et al. 2009). More prolonged drought seasons induced by climatic changes are likely to influence general flammability characteristics of fuel, affecting species composition and live and dead fuel ratio. Moreover, variations in precipitation and mean temperature could directly affect live fuel water content, and length of critical periods of high ignition danger for Mediterranean ecosystems (Westerling et al. 2006; Flannigan et al. 2009; Flannigan et al. 2013; Liu et al. 2013).

Therefore, considering the observed climatic variations and foreseen future scenarios, an evaluation of the impact of these variations on fire danger seems essential.

The climate data provided by the general circulation models (GCMs) are characterized by low resolution and are often not recommended for application at local scale. This constraint could be overcame by using the weather generator approach. Weather generators linked to climate model can transform the raw outputs from the climate models into data with more realistic structure and create synthetic weather series representing present and future climates at local scale.

The main aim of this work was to propose a novel methodology for evaluating the possible impacts of future climate changes on moisture dynamic and length of fire danger period at local scale in the Mediterranean area. Specific objectives were: i) identify threshold values for drought indices that indicate the length of fire season due to fuel status in Mediterranean shrubland, and ii) simulate the potential impacts of future climate changes on the duration of fire danger period.

\section{Methods}

The study was carried out in a nature reserve located in North Western Sardinia, Italy $\left(40^{\circ} 36^{\prime} \mathrm{N} ; 8^{\circ}\right.$ 09' E, $30 \mathrm{~m}$ a.s.1.). The climate is Mediterranean with water deficit conditions occurring from May through September and precipitation mainly concentrated in autumn and winter. The mean annual rainfall is $640 \mathrm{~mm}$ and the mean annual air temperature is $16.8{ }^{\circ} \mathrm{C}$. The vegetation cover of the study area consists mainly of Mediterranean maquis and garigue, grown after a fire event occurred in mid '70s.

Moisture content of live fuel (LFMC) was determined periodically for 8 years on three shrub species: Cistus monspeliensis L., Juniperus phoenicaea L., and Rosmarinus officinalis L., which are very common species in the Western Mediterranean Basin. Samples of live fine fuel, consisting of terminal twigs with diameter not greater than $6 \mathrm{~mm}$, were collected from each species.

To determine the live fuel moisture, three samples of each species were weighed, dried and reweighed. Live fine moisture content was expressed as a percentage of dry weight. Meteorological data were also collected from an automated weather station located in the study site.

Drought conditions that occurred during the LFMC sampling period were assessed by calculating the Drought Code (DC) of the Canadian Forest Fire Weather Index System (Van Wagner 1987). DC is widely used worldwide in wildfire danger assessment as an indicator of the moisture content of very slow drying fuels and its values have been shown to be associated with occurrence of drought (Girardin et al. 2004; Wotton 2009). DC is similar to other drought models such as the Keetch-Byram Drought Index (Keetch and Byram 1968; Burgan 1988) and the Palmer Drought Index (Palmer 1965) and is calculated from daily rainfall and air temperature. Previous studies showed that DC is well related to LFMC of shrub species (Pyne et al. 1996; Viegas et al. 2001). In the current FWI System, DC values equal to 0 correspond to saturation moisture content, with increasing values indicating drier conditions without a specific maximum value (Van Wagner 1987). In this work, the DC code was calculated using the equations given by Van Wagner and Pickett (Van Wagner and Pickett 1985)

Analysis of cumulative distribution curves of DC values for only those days characterized by LFMC values over the critical threshold for fire ignition and spread was performed in order to identify the DC values that indicate the end of the fire danger season. Based on available literature, LFMC 
values below $95 \%$ were used as threshold values for indicating ignition and fire spread danger over Mediterranean shrubs.

The M\&Rfi weather generator (Dubrovsky et al 2004) linked to climate change scenarios derived from 17 available General Circulation Models (GCMs) (see Table 1 for details) was used to produce synthetic weather series, representing present and future climates, for four selected sites located in North Sardinia, Italy. The projected future climates were then used to determine the expected changes of the fire season length.

Table 1. General Circulation Models (GCMs) used in conjunction with the M\&Rfi weather generator to produce synthetic weather series representing present and future climates at four location in North Sardinia, Italy.

\begin{tabular}{|l|l|}
\hline BCM2 & Bjerknes Centre for Climate Research, Norway \\
\hline CGMR & Canadian Center for Climate Modelling and Analysis, Canada \\
\hline CNCM3 & Centre National de Recherches Meteorologiques, France \\
\hline CSMK3 & Commonwealth Scientific and Industrial Res. Organisation, Australia \\
\hline ECHOG & $\begin{array}{l}\text { Met. Inst. Univ. Bonn + Met. Res. Inst., Korea + Model and Data Groupe at MPI-M, } \\
\text { Germany }\end{array}$ \\
\hline GFCM20 & Geophysical Fluid Dynamics Laboratory, USA \\
\hline HADCM3 & UK Met. Office, UK \\
\hline HADGEM & UK Met. Office, UK \\
\hline INCM3 & Institute for Numerical Mathematics, Russia \\
\hline MIMR & National Institute for Environmental Studies, Japan \\
\hline MPEH5 & Max Planck Institute for Meteorology, Germany \\
\hline MRCGCM & Meteorological Research institute, Japan \\
\hline NCCCSM & National Centre for Atmospheric Research, USA \\
\hline NCPCM & National Centre for Atmospheric Research, USA \\
\hline GFCM21 & Geophysical Fluid Dynamics Laboratory, USA \\
\hline GIER & Geophysical Fluid Dynamics Laboratory, USA. Model E20/Russel \\
\hline IPCM4 & Institute Pierre Simon Laplace, France \\
\hline
\end{tabular}

\section{Results}

In general, LFMC values of all species were correlated with the Drought Code values. The analysis showed significant and negative correlation between LFMC and DC for all species $(\mathrm{P} \leq 0.05)$. High correlation coefficients were obtained for Cistus and Rosmarinus throughout the entire study period $(\mathrm{P} \leq 0.01)$. Similar results were also observed for the KBDI $(\mathrm{P} \leq 0.05)$.

LFMC and DC patterns were also compared with the purpose of evaluating whether or not DC values could be useful to describe the seasonal changes of LFMC.

DC and KBDI patterns were very close to LFMC during the rising phase of moisture content (from mid-summer to autumn). During the moisture falling phase (from mid-spring to the beginning of summer), although the weather indices are correlated to LFMC values, the response of both codes does not match very well the short-term variations of LFMC due to resprouting and flowering phases of plants (Fig.1). Therefore, it seems more appropriate the use of the codes to identify the end of fire danger season rather than the date of starting. 
With the purpose of evaluating the effectiveness of both indices, we performed the analysis of frequency distribution as suggested by Andrews et al (2003). Figure 2 shows the distribution of DC and KBDI for all days from July 1 (plots on the top), and only for those days from July 1 with LFMC values higher than $95 \%$ (plots on the bottom). For DC the distribution shifts to the right, with most of the DC values below 700, when the analysis is performed using only days with LFMC higher than 95\%. This behavior is less pronounced in the case of KBDI, so that Drought Code seems to be a better indicator for predicting the end of fire danger season than KBDI.

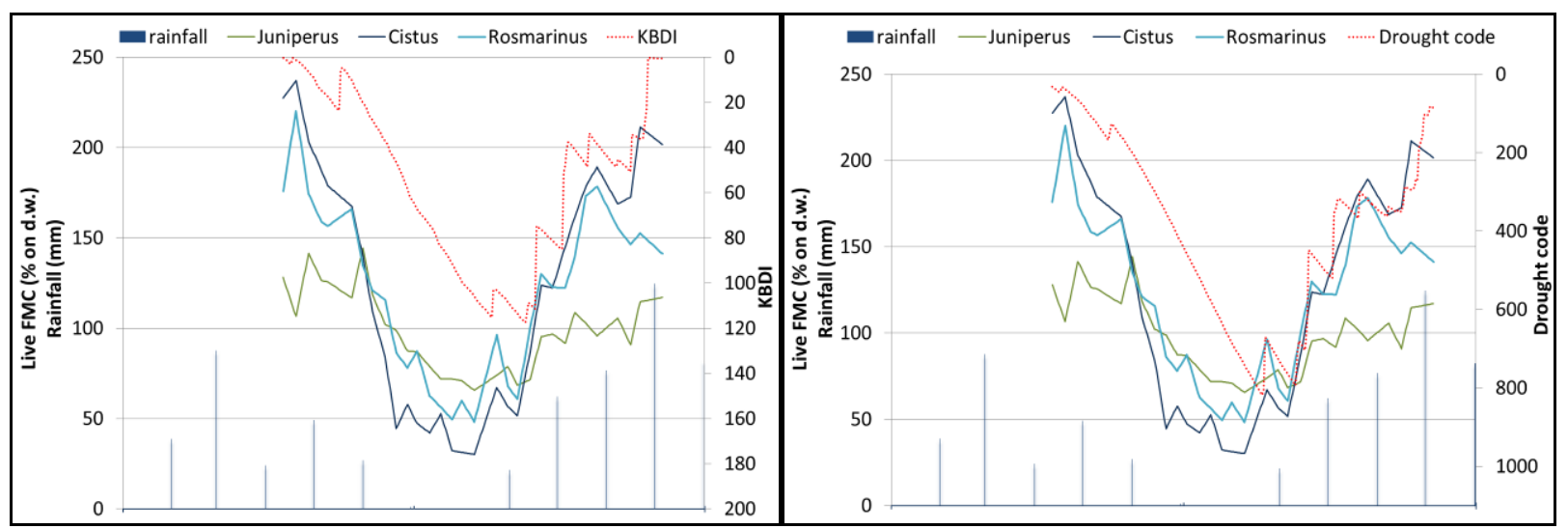

Figure 1. Seasonal trends of Keetch and Byram (KBDI) and Drought Code (DC) and live fuel moisture content (LFMC) values observed for Cistus monspeliensis, Juniperus phoenicaea and Rosmarinus officinalis at the experimental site during April-November 2005.

(a)

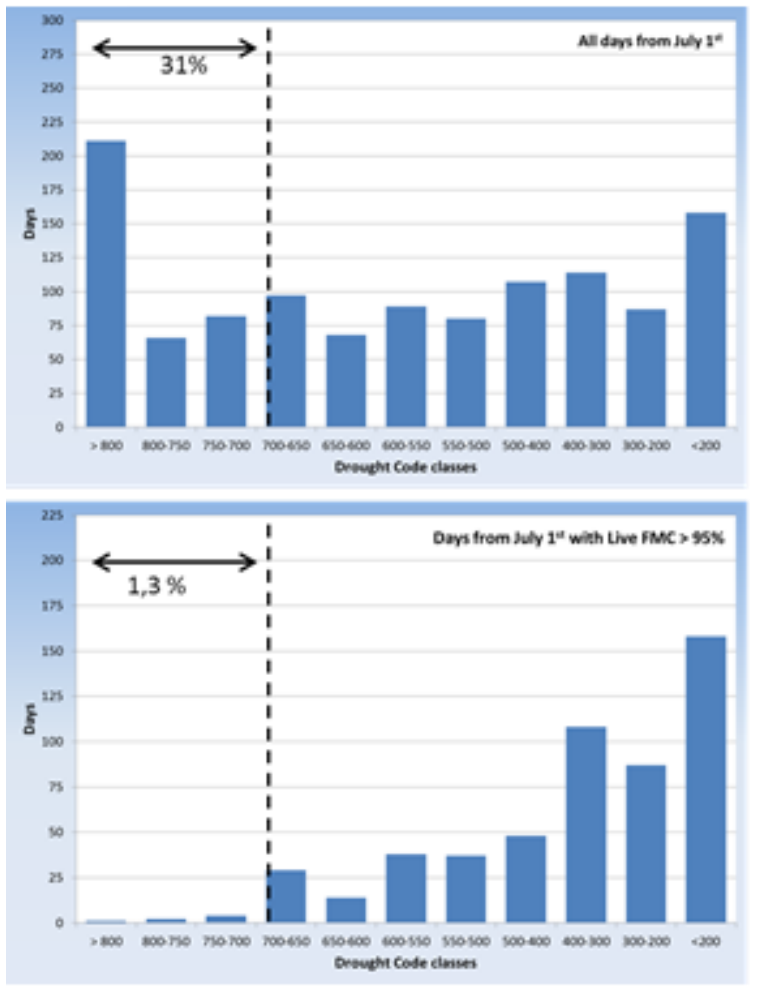

(b)

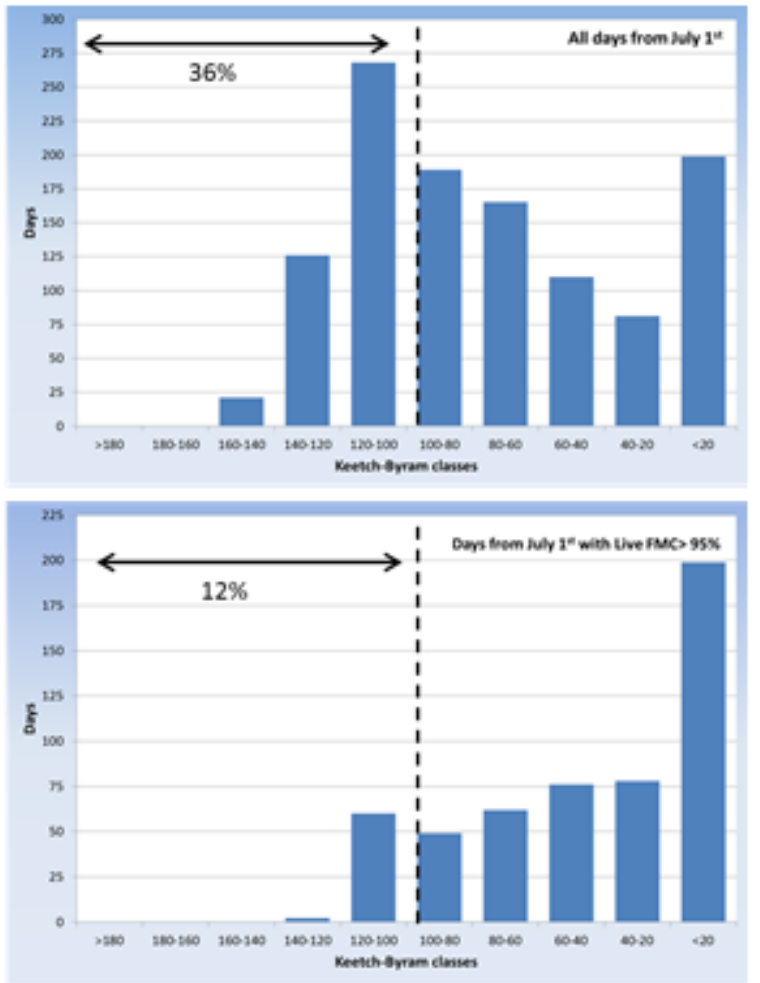

Figure 2. Frequency distribution of Drought Code (a) and Keetch and Byram Drought Index (b) for all days from July 1 (plots at the top) and for all days from July 1 with LFMC values higher than 95\%. 
The cumulative distribution curves of DC (LFMC rising phase), calculated for all days from July 1 with LFMC values above 95\%, shows that most of the DC values are below 700 when LFMC values are above the critical moisture threshold of $95 \%$ (Figure 3). Therefore, a DC threshold of 700 was used to estimate the end of fire danger season due to LFMC of Mediterranean shrubs.

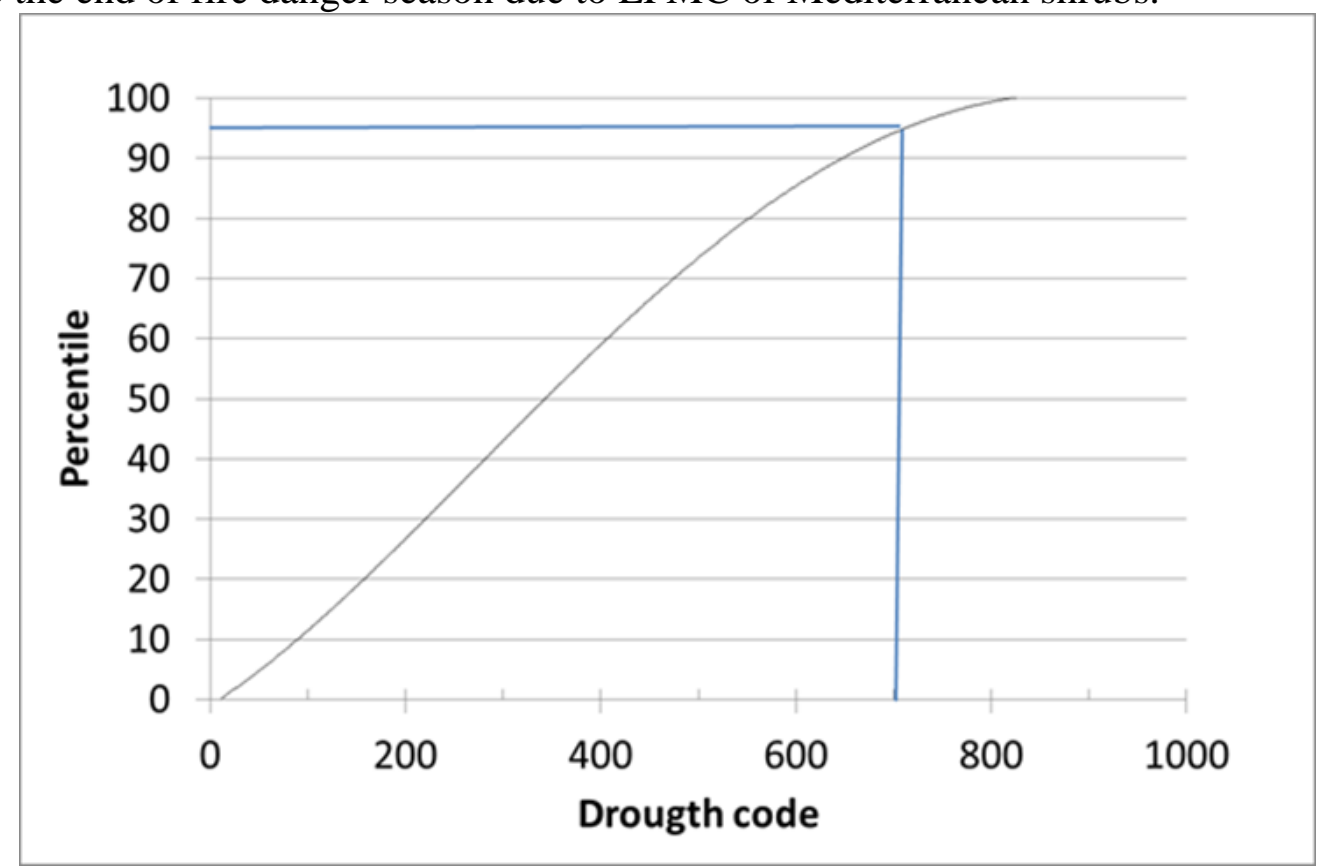

Figure 3. Cumulative distribution of Drought Code values observed during days with LFMC values above 95\% (rising phase of $\mathrm{LFMC}$ ).

Projections of future likely dates of the end of the fire season were obtained using 17 climate change scenarios derived from a subset of available GCMs combined with synthetic weather data from M\&Rfi weather generator.

The actual and projected average dates of the end of fire season for the experimental site are shown in Figure 4 and Table 2. The actual ending date of the fire danger season calculated by using the synthetic weather series is October 14 (DOY $=287$ ). The calculation of the DC values derived from 17 climate change scenarios resulted in a general increase of the duration of the fire danger season. Scenario B1 determines little variations compared to scenarios A2 e A1B. Scenario B1 shows an extension of the fire season ranging from 3 days (2050) to 5 days (2100), with a spread of predictions ranging from 1 to 14 days. Results from scenarios A1B e A2 and mid-century (2050) indicate a possible extension of the fire season of more than 1 week with a spread of the predictions ranging from few days to 3 weeks. For both scenarios A1B and A2, the fire season length indicated by 2100 projections is much larger: about 2 (A1B) and 3 (A2) weeks with a maximum spread of predictions around 1 month. 

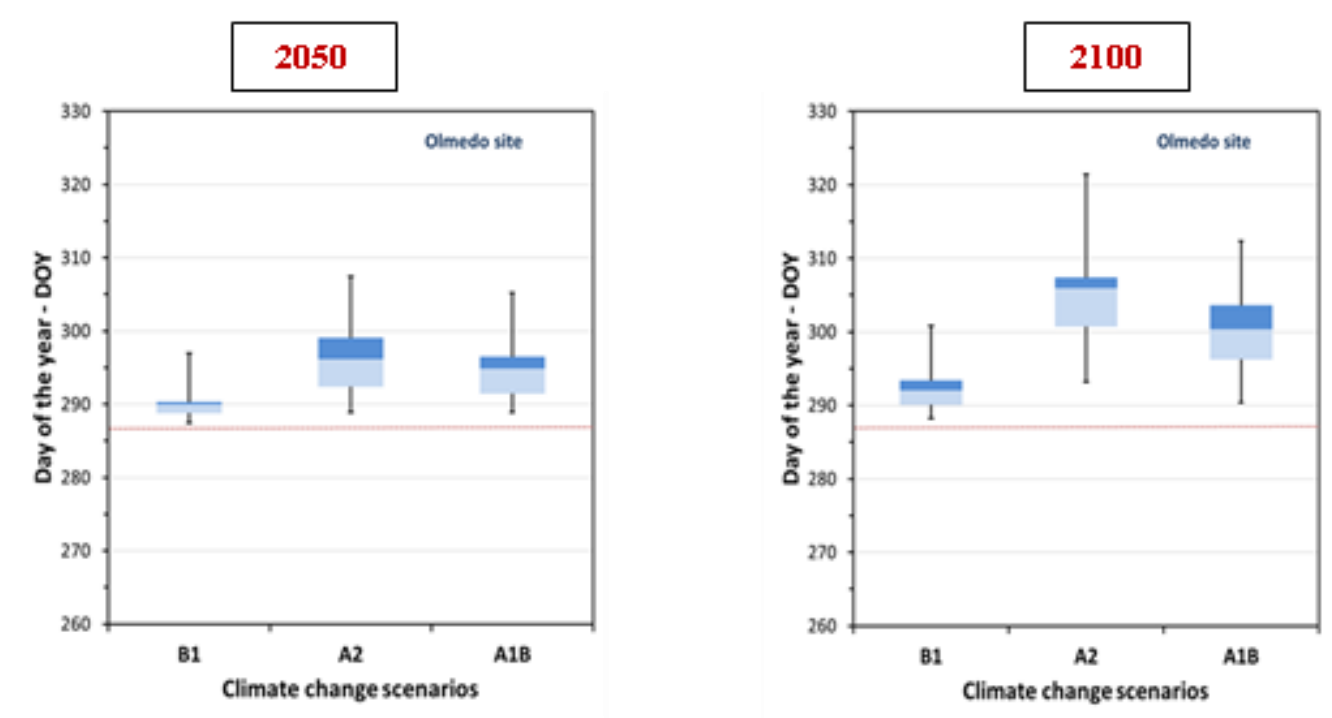

Figure 4. Boxplot of the actual (red) and projected (blue) average fire season ending dates relative to three climate change scenarios (B1, A1B, and A2). The charts show the minimum, maximum and mean values, and the lower and upper quartiles.

Table 2. Projections of future extension of fire season (in days) by climate change scenario and time period. Spread of predictions (in days) are reported in brackets.

\begin{tabular}{cccc}
\hline Years & B1 & A2 & A1B \\
\hline \multirow{2}{*}{2050} & 3 & 9 & 8 \\
& $(1-10)$ & $(2-20)$ & $(2-18)$ \\
\hline \multirow{2}{*}{2100} & 5 & 19 & 13 \\
& $(1-14)$ & $(6-35)$ & $(3-25)$ \\
\hline
\end{tabular}

\section{Conclusions}

The results reported in this paper are based on local data and information and on the calibration of the commonly used DC code. Our study confirms that projected climate scenarios over the Mediterranean area could affect the duration of the fire danger season causing a delay in the ending dates of high ignition danger periods. Several authors suggested that an earlier spring could lead to an earlier fire season (Westerling et al 2006; Flannigan et al 2009; Matthews et al 2012). In this work, we did not investigate on the impact of climate change on starting date of fire season, since weather indices used as a proxy of vegetation moisture content showed poor performances in following the variations of LFMC in spring. During this period, the moisture content of living plants of Mediterranean species is also affected by phenological phases that depends by both endogenous rhythm of the plant and weather conditions occurred before vegetative growth. In this context, the use of models that also include phenological response to weather of Mediterranean shrubs could provide an appropriate tool for a better description of live fuel moisture seasonal changes in Mediterranean shrublands. 


\section{Acknowledgements}

This work was partly supported by the EU $7^{\text {th }}$ Framework Program (FUME) contract number 243888. The authors are also grateful to Mr Angelo Arca and Mr Pierpaolo Masia for their valuable support in the field work.

\section{References}

Agee JK, Wright CS, Williamson N, Huff MH (2002) Foliar moisture content of Pacific Northwest vegetation and its relation to wildland fire behaviour. Forest Ecology and Management 167, 57-66.

Andrews P, Loftsgaargen DO, Bradahaw S (2003) Evaluation of fire danger rating indexes using logistic regression and percentile analysis. International Journal of Wildland Fire 12, 213-226.

Burgan RE (1988) 1988 revisions to the 1978 national fire-danger rating system. Asheville, N.C., U.S. Dept. of Agriculture, Forest Service, Southeastern Forest Experiment Station, pp. 39.

Chandler P, Cheney P, Thomas L, Trabaud L, Williams D (1983) Fire in forestry. Vol. 1. John Wiley \& Sons (New York, USA).

Chuvieco E, Aguado I, Dimitrakopoulos A (2004) Conversion of fuel moisture content values to ignition potential for integrated fire danger assessment. Canadian Journal of Forest Research 34, 2284-2293.

Davis F, Michaelsen J (1995) Sensitivity of fire regime in chaparral ecosystems to climate change. In Global Change and Mediterranean-Type Ecosystems. (Eds JM Moreno, WC Oechel) pp. 435-456. (Springer: NewYork).

Davis FW, Legg CJ, Smith AA, MacDonald AJ (2009) Rate of spread of fires in Calluna vulgarisdominated moorlands. Journal of Applied Ecology 46, 1054-1063.

Dennison PE, Moritz MA, Taylor RS (2008) Examining predictive models of chamise critical live fuel moisture in the Santa Monica Mountains, California. International Journal of Wildland Fire 17, 18 27.

Dimitrakopoulos AP, Papaioannou KK (2001) Flammability Assessment of Mediterranean Forest Fuels. Fire Technology 37, 143-152.

Dubrovsky M, Buchtele J, Zalud Z (2004) High-Frequency and Low-Frequency Variability in Stochastic Daily Weather Generator and Its Effect on Agricultural and Hydrologic Modelling. Climatic Change 63 (1-2), 145-179.

Flannigan MD, Krawchuk MA, de Groot WJ, Wotton BM, Gowman LM (2009) Implications of changing climate for global wildland fire. International Journal of Wildland Fire 18, 483-507.

Flannigan M, Cantin AS, de Groot WJ, Wotton M., Newbery A, Gowman L (2013) Global wildland fire season severity in the 21st century. Forest Ecology and Management 294, 54-61.

Giannakopoulos C, Le Sager P, Bindi M, Moriondo M, Kostopouloua E, Goodess CM (2009) Climatic changes and associated impacts in the Mediterranean resulting from a $2{ }^{\circ} \mathrm{C}$ global warming. Global and Planetary Change. 68, 209-224.

Giorgi F, Bi XQ, Pal J (2004) Mean, interannual variability and trends in a regional climate change experiment over Europe. II: climate change scenarios (2071- 2100). Climate Dynamics 23, 839858.

Girardin MP, Tardif J, Flannigan MD, Wotton BM, Bergeron Y (2004) Trends and periodicities in the Canadian Drought Code and their relationships with atmospheric circulation for the southern Canadian boreal forest. Canadian Journal Forest Research 34(1), 103-119.

Hernando Lara C, Moro C, Valette JC (1994) Flammability parameters and calorific values of Erica arborea and Arbutus unedo. In Proceedings of the 2nd International Conference on Forest Fire Research, Vol. II, 481-489, Coimbra, Portugal. 
Keetch JJ, Byram GM (1968). A drought index for forest fire control. Research Paper SE-38. Asheville, NC, U.S. Department of Agriculture, Forest Service, Southeastern Forest Experiment Station. pp. 32.

Liu Y, Goodrick SL, Stanturf JA, (2013) Future U.S. wildfire potential trends projected using a dynamically downscaled climate change scenario. Forest Ecology and Management 294, 120-135.

Matthews S, Sullivan AL, Watson P, Williams R, (2012) Climate change, fuel and fire behaviour in a eucalypt forest. Global Change Biology, 18 (10), 3212-3223.

Palmer WC (1965) Meteorological drought. Research Paper No. 45. (Washington DC: U.S.) Department of Commerce Weather Bureau.

Pellizzaro G, Duce P, Ventura A, Zara P, (2007 ) Seasonal variations of live moisture content and ignitability in shrubs of Mediterranenan Basin. International Journal of Wildland Fire 16, 633-641.

Piñol J, Filella I, Ogaya R, Peñuelas J. (1998) Ground-based spectroradiometric estimation of live fine fuel moisture of Mediterranean plants. Agricultural and Forest Meteorology 90, 73-186.

Pyne SJ, Andrews PL, Laven R. (1996) Introduction to Wildland Fire, 2nd ed., 769 pp. John Wiley and Sons, (Toronto, Canada)

Schoenberg FP, Peng R, Huang Z, Rundel P (2003) Detection of nonlinearities in the dependence of burn area on fuel age and climatic variables. International Journal of Wildland Fire 12, 1-6.

Van Wagner CE (1977) Conditions for the start and spread of crown fires. Canadian Journal of Forest Research 7,23-34.

Van Wagner CE, Pickett TL (1985) Equation and FORTRAN program for the Canadian Forest Fire Weather Index System. Canadian Forestry Service, Forestry Technical Report 33.( Ottawa, ON, Canada).

Van Wagner CE (1987) The development and structure of the Canadian Forest FireWeather Index System. Canadian Forest Service, Petawawa National Forestry Institute. Chalk River, Ont. FTR35.

Viegas DX, Pinol J, Viegas MT, Ogaya R (2001) Estimating live fine fuels moisture content using meteorologically-based indices. International Journal of Wildland Fires 10, 223-240.

Wotton M (2009) Interpreting and using outputs from the Canadian Forest Fire Danger Rating System in research applications. Environmental and Ecological Statistics 16, 107-131.

Westerling AL, Hidalgo HG, Cayan DR, Swetnam TW (2006) Warming and Earlier Spring Increase Western U.S. Forest Wildfire Activity. Science 313, 940-943. 